\author{
ゾルーゲル法によるホタテ貝殼からの \\ ハイドロキシアパタイト合成と結晶形状特異性
}

\author{
小林 淳哉 ${ }^{1 *} \cdot$ Kelvin Ng WIJAYA ${ }^{2}$
}

\title{
Shape Specificity of Crystal of Hydroxyapatite Synthesized by Sol-Gel Method from Scallop Shell
}

\author{
Junya KOBAYASHI ${ }^{1 *}$ and Kelvin Ng WIJAYA ${ }^{2}$ \\ ${ }^{1}$ National Institute of Technology, Hakodate College, Hokkaido 042-8501, Japan \\ ${ }^{2}$ Department of Environmental and Life Science, Toyohashi University of Technology, Aichi 441-8580, Japan
}

\begin{abstract}
We synthesized hydroxyapatite (HAp) by the sol-gel method based on reaction of phosphoric acid and the calcium acetate obtained by dissolving scallop shells in acetic acid. The synthesized HAp was the crystal that is flat and elliptical shape (50-100 nm). On the other hand, HAp from the commercial calcium acetate is large crystal of irregular shape. $\mathrm{Mg}^{2+}, \mathrm{K}^{+}$and $\mathrm{Na}^{+}$ions were contained in HAp from scallop shell. Effective utilization of waste scallop shell as a high value-added product such as adsorbent or artificial biomaterial can be expected.
\end{abstract}

Key words: Hydroxyapatite, Sol-Gel Method, Shape specificity

1. 目的

ホタテガイの漁獲量は平成 26 年度で約 23 万トンであ り，産業廃棄物としての貝殼の重量はその約半分を占め る。ホタテガイ貝殼は土壌改良剤などに活用されている が, リサイクルの主たる目的は, 廃棄物の保管用地確保 であり, 製品価格とリサイクルコストの関係からすると, より高付加価値な製品へ再利用することが期待される。 また，貝款の主成分は炭酸カルシウムであるが，同じく 炭酸カルシウムを主成分とする石灰石の生産量が年間約 1 億 7 千万トンであることから, 石灰石に由来する原料 からの製品との差別化も重要である。

ハイドロキシアパタイト（以後 HAp）は吸着剂や骨 充填材などの医療用材料として付加価值が高い。一方, ゾルーゲル法は, 金属アルコキシドの加水分解による無 機材料合成法であり, 合成された粒子が微粒子化, 粒径 均一性を示すことが多いのが特徴である!。そこで，本 研究では, ホタテガイ貝殼を原料としたゾルーゲル法に

キーワード：ハイドロキシアパタイト，ゾルーゲル法, 形状特異性

1 函館工業高等専門学校

2 豊橋技術科学大学生命環境工学科

平成 29 年 8 月 17 日受理

*e-mail: kobayasi@hakodate-ct.ac.jp
よるハイドロキシアパタイトの合成方法を見出し，さら に貝殼を利用することによる粒子形状の特徴を明らかに することを目標とした。

\section{2. 実験方法}

\section{1 ゾル-ゲル法による HAp 合成}

ホタテガイ貝殼を空気中 $800^{\circ} \mathrm{C} て ゙ 3 \mathrm{~h}$ 焼成し, 焼成物 を $0.1 \mathrm{~mol} / \mathrm{L}$ の酢酸水溶液に溶解させた。溶解せずに残 存した貝殼をろ過後, ろ液をロータリーエバポレーター で蒸発乾燥させたのち, さらに乾燥器で $110^{\circ} \mathrm{C}, 1 \mathrm{~h}$ 乾 燥させた。その後, 乾燥試料はエチレングリコールに溶 解させた。このエチレングリコール溶液に対し, リン酸 溶液を $4^{\circ} \mathrm{C}$ の環境下で滴下してゲルを生成させた。リ ン酸の滴下量は, 貝殼を酢酸に溶解させ乾燥させた試料 が酢酸カルシウムであると仮定し, $\mathrm{HAp}\left(\mathrm{Ca}_{5}\left(\mathrm{PO}_{4}\right)_{3}(\mathrm{OH})\right)$ 中のカルシウムとリンの化学量論比から $\mathrm{Ca}: \mathrm{P}=5: 3$ のモ ル比になるよらにした。

生成したゲルをロータリーエバポレーターで乾燥後, さらに乾燥器で $110^{\circ} \mathrm{C}, 24 \mathrm{~h}$ 乾燥させた。乾燥試料は, 赤外線イメージ炉にセットし, 純水に窒素ガスをバブリ ングさせて発生させた $\mathrm{H}_{2} \mathrm{O} / \mathrm{N}_{2}$ を導入しながら焼成した。 焼成は, 室温から $30 \mathrm{~min}$ で $600^{\circ} \mathrm{C}$ まで昇温し, $2 \mathrm{~h}$ 保持 後, 引き続き $800^{\circ} \mathrm{C}$ まで $20 \mathrm{~min}$ かけて昇温し, $2 \mathrm{~h}$ 保持

Vol. 64, No. 3 (2017) 
後, 室温まで自然冷却することで行った。同様の方法で, 市販の酢酸カルシウムをエチレングリコールに溶解させ た場合の実験も行った。

\section{2 キャラクタリゼーション}

調製した試料は $\mathrm{Cu} \mathrm{K \alpha}$ を用いた X 線回折 (以後 XRD) で結晶構造を明らかにした。また,フィールドェミッショ ン走査電子顕微鏡（以後 FE-SEM）で結晶形状を観察し た。比較のため, 市販の 2 種類のハイドロキシアパタイ ト（ワコー純薬製：カタログ番号011-14882, Hydroxyapatite, monoclinic, 以後 HAp-WAKO と太平化学産業製, 製品名 HAP-100）もまた測定した。なお，HAP-100 は 人工骨・人工歯根等の生体材料, 骨充填剂, カラムクロ マト用充填剂としての用途を持つ。

ゾルーゲル法で合成した試料は, 波長分散型蛍光 X 線 分析（以後 XRF）により，微量金属元素を定量した。

\section{3. 結果と考察}

\subsection{XRD による結晶構造の解析}

Fig. 1 に酢酸水溶液に溶解後に乾燥させた試料の XRD パターンを示した。

$2 \theta=10-30^{\circ}$ の範囲の主要ピークは酢酸カルシムの回 折線と一致した。 $30^{\circ} よ り$ 高角度側に現れた多数のピー クもまた大部分は酢酸カルシウムに一致したが, 未確定 のピークもある。以後はこの乾燥試料をホタテガイ由来 の酢酸カルシウムとして取り扱らこととした。

Fig. 2 にホタテガイ貝殼由来あるいは市販の酢酸カル シウムを原料としてゾルーゲル法で合成した試料と, 市 販の 2 種類の HAp の XRD パターンを示した。

ゾルーゲル法で合成した試料は, 酢酸カルシウムが貝 殼に由来するかどらかによらず, 市販品との比較から HAp であった。HAp には単斜晶系と六方晶系があり, 一般には空間群 $P 63 / m$ の六方晶系として表される。単 斜晶系の HAp は, $200^{\circ} \mathrm{C}$ 以上では六方晶系に相転移する ことから ${ }^{2}$, 今回の焼成条件では JCPDS カード (9-0492) などに代表される六方晶系であると推定している。なお,

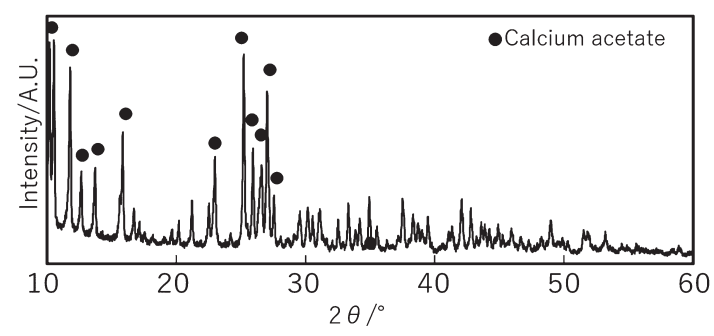

Fig. 1 XRD pattern of a sample obtained by drying the solution after dissolution of scallop shell with acetic acid.
HAp-WAKOは製品名からは単斜晶系であるが, HAP-100 にはその記載はないが, 六方晶系であると考えられる。

ホタテガイ貝殼を原料としてゾルーゲル法で合成した 試料はXRF 分析からナトリウムが $1.01 \%$, マグネシウ ムが $0.65 \mathrm{wt} \%$, カリウムが $0.19 \%$ 含まれていた。これ らの金属元素はカルシウムイオンと置換して, 六方晶系 をとっていると推定している3。

\subsection{FE-SEM による結晶形状観察}

Fig. 3 に焼成後の各試料の FE-SEM 写真を示した。ホ タテガイ貝殼からの酢酸カルシウムを原料とした場合, 50-100 nm の扁平な形状の HAp が観察された。一方, 市販の酢酸カルシウムを用いた場合には，特徵ある形状 を示さず，焼成処理により焼結も進んでいる。なお， HAp-WAKO の HAp は単斜晶系の柱状構造であり,

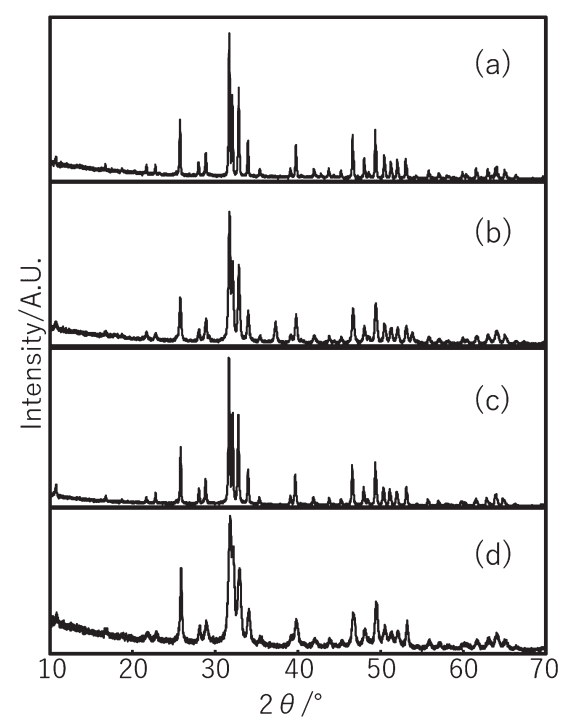

Fig. 2 XRD patterns of samples synthesized from (a) calcium acetate derived from scallop shell and (b) commercial calcium acetate, and (c) HAp-WAKO, and (d) HAP-100.
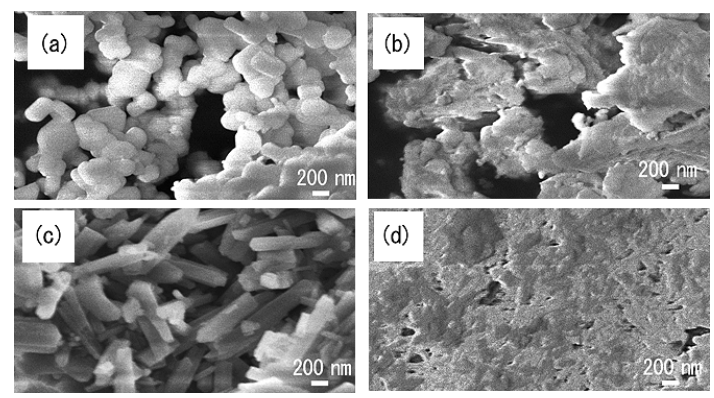

Fig. 3 FE-SEM images of HAps from (a) scallop shell and (b) commercial calcium acetate, and (c) HAp-WAKO, and (d) HAP-100. 


$$
\text { ゾルーゲル法によるホタテ貝殼からのハイドロキシアパタイト合成と結晶形状特異性 }
$$

HAP-100はより小さな柱状の結晶が凝集している。今 回ホタテガイ貝殼からゾルーゲル法で合成した HAp が特 異的な構造を取った原因は，貝殼中の $\mathrm{Mg}^{2+}, \mathrm{Na}^{+}, \mathrm{K}^{+}$ が $\mathrm{Ca}^{2+}$ イオンと置換して固溶することによる結晶成長 が関係していると考えている。したがって，ホタテガイ 貝殼には, HAp の特徵的な結晶成長を促す金属イオン があらかじめセットされているとみなすことができ, 貝 殼の高付加価值製品への展開が期待できる。

\section{4. 結言}

ホタテ貝殼に由来する酢酸カルシウムからゾルーゲル 法で扁平な形状を持つ HAp を合成できた。また, HAp 中にマグネシウムイオンを含むことは骨芽細胞の成長に 有利であるので, 貝殼を原料とすることはバイオ七ラ ミックスとしての用途で利点となる可能性がある。こう した用途への活用を目指すために, タンパク質など有機
物の吸着活性を評価する必要がある。さらに, HApの 形状や組成は, 反応中の溶液の $\mathrm{pH}$ の影響も受けること が知られている 4 。また, ホタテ貝殼は産地や生育環境 で微量金属イオン量がわずかに異なることも知られてい るので，貝殼の個体差や調製条件が結晶形状に与える影 響を明らかにしていくことが今後の研究課題である。

\section{References}

1. A. Ueno: Hyomen no Kagaku,Gakkai Shuppan Center (Tokyo), pp. 325 (1985)

2. T. Saito, K. Hashimoto, Y. Toda: J. Jpn. Soc. Colour Materi., 70, 1, pp. 26-34 (1997)

3. A. Bigi, G. Falini, E. Foresti, M. Gazzano, A. Ripmonti, N. Roveri: Acta Cryst., B52, pp. 87-92 (1996)

4. Y. Masuda, K. Matsubara, S. Sakka: J. Ceram. Soc. Jpn., 98, 1143, pp. 1255-1266 (1990) 